\title{
PENERAPAN MODEL ARIMAX-GARCH DALAM PEMODELAN DAN PERAMALAN VOLUME TRANSAKSI UANG ELEKTRONIK DI INDONESIA
}

\author{
Christopher Andreas ${ }^{1}$, Sediono $^{2 *}$, Elly Ana ${ }^{3}$, Suliyanto ${ }^{4}$, M. Fariz Fadillah \\ Mardianto ${ }^{5}$ \\ 1, 2, 3, 4, 5 Program Studi Statistika, Departemen Matematika, Fakultas Sains dan \\ Teknologi, Universitas Airlangga, Surabaya, Indonesia \\ christopher.andreas-2018@fst.unair.ac.id ${ }^{1}$, sediono101@gmail.com*2, elly- \\ a@fst.unair.ac.id ${ }^{3}$, suliyanto@fst.unair.ac.id ${ }^{4}$, m.fariz.fadillah.m@fst.unair.ac.id ${ }^{5}$. \\ *Corresponding Author
}

Received 08 December 2021; revised 21 December 2021; accepted 23 December 2021.

\begin{abstract}
ABSTRAK
Di era ekonomi digital, berbagai aktivitas ekonomi telah banyak memanfaatkan penggunaan uang elektronik. Penggunaan uang elektronik memberi berbagai dampak positif terhadap perekonomian dan pertumbuhan ekonomi. Untuk itu, perkembangan ekonomi digital terus didorong dalam upaya untuk meningkatkan pertumbuhan ekonomi seperti salah satu pilar tujuan dari Sustainable Development Goals (SDGs). Hal ini menunjukkan bahwa pemodelan dan peramalan volume transaksi uang elektronik sangat penting untuk dilakukan karena volume transaksi uang elektronik tersebut merupakan salah satu indikator perkembangan ekonomi digital di Indonesia. Penelitian ini bertujuan untuk menciptakan model statistika yang memiliki akurasi tinggi guna meramalkan volume transaksi uang elektronik di Indonesia. Dalam hal ini, pemodelan dilakukan dengan mempertimbangkan dua variabel eksogen yaitu infrastruktur uang elektronik dan kondisi pandemi Covid-19. Penelitian ini dilakukan dengan melakukan analisis data berdasarkan data yang bersumber dari Bank Indonesia. Dengan menerapkan model ARIMAXGARCH, diperoleh model statistika yang memiliki akurasi tinggi dalam meramalkan volume transaksi uang elektronik di Indonesia. Hal ini ditandai melalui nilai Mean Absolute Percentage Error (MAPE) sebesar 11,33\%. Selain itu, kedua variabel eksogen yaitu infrastruktur uang elektronik dan kondisi pandemi Covid-19 berpengaruh signifikan terhadap volume transaksi uang elektronik di Indonesia. Penelitian ini bermanfaat sebagai landasan dalam melakukan evaluasi kebijakan terkait perkembangan ekonomi digital khususnya penggunaan uang elektronik di Indonesia.
\end{abstract}

Kata kunci: ARIMAX-GARCH, infrastruktur uang elektronik, pandemi Covid-19, peramalan, volume transaksi uang elektronik. 


\begin{abstract}
In the era of the digital economy, various economic activities have taken advantage of the use of electronic money. The use of electronic money has various positive impacts on the economy and economic growth. For this reason, the development of the digital economy continues to be encouraged in an effort to increase economic growth as one of the pillars of the goals of the Sustainable Development Goals (SDGs). This shows that modeling and forecasting the volume of electronic money transactions is very important because the volume of electronic money transactions is one indicator of the development of the digital economy in Indonesia. This study aims to create a statistical model with high accuracy to predict the volume of electronic money transactions in Indonesia. In this case, modeling is carried out by considering two exogenous variables, namely electronic money infrastructure and the condition of the Covid-19 pandemic. This research was conducted by analyzing data based on data sourced from Bank Indonesia. By applying the ARIMAX-GARCH model, a statistical model is obtained that has high accuracy in predicting the volume of electronic money transactions in Indonesia. This is indicated by the Mean Absolute Percentage Error (MAPE) value of 11,33\%. In addition, the two exogenous variables, electronic money infrastructure, and the Covid-19 pandemic have a significant effect on the volume of electronic money transactions in Indonesia. This study is useful as a basis for evaluating policies related to the development of the digital economy, especially the use of electronic money in Indonesia.
\end{abstract}

Keywords: ARIMAX-GARCH, electronic money infrastructure, Covid-19 pandemic, forecasting, electronic money transaction volume.

\title{
PENDAHULUAN
}

Pandemi Coronavirus Disease 2019 (Covid-19) telah mendorong transformasi ekonomi digital bergerak semakin cepat di berbagai negara (Organisation for Economic Co-operation and Development, 2020). Transformasi ekonomi digital tersebut sejalan dengan upaya dalam pilar Sustainable Development Goals (SDGs) yang bertujuan untuk meningkatkan pertumbuhan ekonomi melalui kemudahan aktivitas ekonomi. Kemudahan aktivitas ekonomi tersebut tercermin dalam penggunaan uang elektronik yang biasa dikenal dengan e-money. Penggunaan uang elektronik dalam aktivitas ekonomi mampu menciptakan berbagai manfaat seperti kemudahan dan kecepatan dalam bertransaksi, serta efisiensi biaya yang tinggi (Kanmar, 2014). Selain itu, 
penggunaan uang elektronik terbukti mampu meningkatkan kecepatan perputaran uang dan berdampak positif terhadap kegiatan konsumsi, perdagangan, dan pertumbuhan ekonomi (Ulfi, 2020).

Di Indonesia, percepatan proses transformasi ekonomi digital telah berlangsung sejak tahun 2014 yang ditandai dengan Gerakan Nasional Non Tunai (GNNT). Selain itu, Bank Indonesia juga menerapkan berbagai program elektronifikasi yang mengubah cara pembayaran tunai menjadi non tunai di berbagai sektor kehidupan, seperti pemerintahan dan sektor transportasi (Bank Indonesia, 2020). Hal ini membuat penggunaan uang elektronik di Indonesia meningkat dengan pesat. Bank Indonesia menunjukkan bahwa volume transaksi uang elektronik di Indonesia pada Januari 2021 telah mencapai 381 juta transaksi. Nilai tersebut meningkat signifikan dibandingkan dengan Januari 2018 yang memcatatkan volume transaksi sebesar 215 juta transaksi. Selain itu, nilai transaksi uang elektronik pada Januari 2021 telah mencapai lebih dari 20 triliun rupiah (Bank Indonesia, 2021a).

Peningkatan volume transaksi uang elektronik tersebut didukung dengan infrastruktur uang elektronik di Indonesia yang semakin memadai. Pada tahun 2021, jumlah mesin reader sebagai infrastruktur uang elektronik di Indonesia telah mencapai 650 ribu. Nilai ini mengalami peningkatan signifikan dimana jumlah mesin reader pada tahun 2018 masih dibawah 400 ribu (Bank Indonesia, 2021b). Lebih lanjut, pemerintah juga mendorong pemakaian uang elektronik di masyarakat sebagai bagian dari upaya pemutusan penyebaran Covid-19 yang dikenal dengan gerakan cashless (Indrawati, et. al., 2021). Hal ini dilakukan karena risiko penyebaran Covid-19 melalui uang elektronik dinilai lebih rendah dibandingkan melalui uang kertas. Kondisi ini tentunya ikut mempengaruhi volume transaksi uang elektronik di Indonesia.

Penelitian untuk melakukan pemodelan dan peramalan terhadap volume transaksi uang elektronik di Indonesia sangat penting untuk dilakukan. Dengan adanya penelitian tersebut, evaluasi kebijakan terkait perkembangan ekonomi digital di Indonesia, khususnya penggunaan uang elektronik, dapat dilakukan sebagai landasan dalam upaya peningkatan pertumbuhan ekonomi melalui ekonomi digital. Hal ini penting karena evaluasi kebijakan sangat membutuhkan 
nilai peramalan pada periode waktu selanjutnya (Wolters dan Wieland, 2012; Uyah, et. al., 2021).

Berdasarkan penelitian terdahulu, Sediono, et. al. (2021) telah melakukan analisis intervensi terhadap volume transaksi uang elektronik di Indonesia. Melalui penelitiannya, Sediono, et. al. (2021) menunjukkan bahwa penggunaan model intervensi terhadap volume transaksi uang elektronik telah memiliki akurasi yang baik yang ditinjau dari ukuran akurasi berupa Mean Absolute Percentage Error (MAPE) sebesar 12,24\%. Namun, pada penelitian tersebut, pemodelan hanya dibangun berdasarkan pengaruh nilai pengamatan pada periode tertentu. Dalam penelitian ini, pemodelan volume transaksi uang elektronik dilakukan dengan mempertimbangkan pengaruh dari variabel eksogen yaitu infrastruktur uang elektronik dan kondisi pandemi Covid-19. Pendekatan yang digunakan adalah kombinasi dari dua model time series. Model time series tersebut adalah model Autoregressive Integrated Moving Average with Exogenous Variable (ARIMAX) dan model Generalized Autoregressive Conditional Heteroskedasticity (GARCH) yang disebut sebagai model ARIMAX-GARCH.

Model ARIMAX pada dasarnya dibentuk dari model dasar yang dikenal dengan model Autoregressive Integrated Moving Average (ARIMA). Model ARIMAX memiliki sejumlah kelebihan yaitu mampu mempertimbangkan pengaruh nilai pengamatan pada periode tertentu, serta dapat mempertimbangkan pengaruh sejumlah variabel eksogen terhadap variabel respon (Cryer dan Chan, 2008). Dengan model ARIMAX, signifikansi pengaruh variabel eksogen dapat diidentifikasi dengan jelas seperti penelitian Andreas, et. al. (2021b) yang menunjukkan pengaruh signifikan antara perang dagang Amerika dan China terhadap harga emas. Selain itu, peramalan harga minyak mentah Brent juga menunjukkan hasil akurasi yang baik dengan model ARIMAX (Rahmayanti, et. al., 2021).

Namun, pola data aktual yang bersumber dari industri keuangan, perdagangan, dan ekonomi pada umumnya memiliki karakteristik variansi yang tidak konstan pada residual. Hal ini menyebabkan model ARIMAX mengalami kasus heteroskedastisitas. Oleh sebab itu, diperlukan model GARCH yang mampu mengatasi hal tersebut (Tsay, 2010). Dengan demikian, penggunaan model 
ARIMAX-GARCH mampu memberikan hasil peramalan yang baik dengan tetap memenuhi asumsi yang berlaku seperti tidak adanya kasus heteroskedastisitas. Model ARIMAX-GARCH mampu memberi hasil peramalan yang baik dalam berbagai pemodelan seperti peramalan nilai inflasi di Indonesia (Aryani, et. al., 2015).

Penerapan model ARIMAX-GARCH untuk meramalkan volume transaksi uang elektronik di Indonesia menjadi salah satu kebaharuan penelitian ini. Selain itu, penggunaan variabel eksogen berupa infrastruktur uang elektronik dan kondisi pandemi Covid-19 dalam pemodelan volume transaksi uang elektronik di Indonesia juga merupakan kebaharuan penelitian ini. Dalam hal ini, akurasi model ditinjau dari ukuran MAPE dan Akaike's Information Criterion (AIC). Penelitian ini menghasilkan model Statistika dan nilai peramalan terkait volume transaksi uang elektronik di Indonesia pada sejumlah periode waktu selanjutnya. Hal ini sangat bermanfaat sebagai landasan dalam melakukan evaluasi kebijakan terkait perkembangan ekonomi digital khususnya penggunaan uang elektronik di Indonesia.

\section{METODE PENELITIAN}

Sumber data yang digunakan dalam penelitian ini adalah website resmi Bank Indonesia. Data tersebut berupa data bulanan sejumlah 100 data yang terbagi menjadi data training sebanyak 96 data, serta data testing sebanyak 4 data. Data yang digunakan dalam proses pemodelan disebut sebagai data training yaitu sejak Januari 2013 hingga Desember 2020. Sedangkan, pengukuran akurasi dan kebaikan model dilakukan melalui data testing yaitu data sejak Januari 2021 hingga April 2021. Variabel penelitian yang digunakan terdiri atas tiga variabel. Secara lengkap, variabel penelitian tersebut ditampilkan pada Tabel 1.

Tabel 1. Variabel Penelitian.

\begin{tabular}{ll}
\hline \multicolumn{1}{c}{ Variabel Penelitian } & \multicolumn{1}{c}{ Keterangan } \\
\hline Volume transaksi uang elektronik $(Y)$ & Dalam satuan transaksi. \\
Infrastruktur uang elektronik $(X)$ & Berupa mesin reader dengan satuan \\
& jumlah. \\
Pandemi Covid-19 di Indonesia $(P)$ & Berupa variabel dummy. \\
\hline
\end{tabular}


Variabel dummy yang digunakan pada variabel pandemi Covid-19 tersebut adalah sebagai berikut:

$$
P=\left\{\begin{array}{lr}
1, & \text { sejak Maret } 2020 \\
0, & \text { sebelum Maret } 2020
\end{array}\right.
$$

Penelitian ini menggunakan tingkat kesalahan sebesar 5\%. Prosedur teknik analisis yang diterapkan pada penelitian ini secara sistematis adalah sebagai berikut (Tsay, 2010) :

1. Mendeskripsikan data penelitian melalui statistika deskriptif.

2. Melakukan regresi antara variabel eksogen terhadap variabel respon.

3. Melakukan pemodelan ARIMA berdasarkan nilai error yang diperoleh dari hasil regresi sebelumnya. Tahapan pemodelan ini adalah sebagai berikut:

a. Melakukan uji stasioneritas.

b. Melakukan identifikasi model dan estimasi parameter dengan metode Least Square.

c. Melakukan pengujian signifikansi parameter.

d. Melakukan evaluasi model dan memilih model terbaik.

e. Melakukan pemeriksaan asumsi.

4. Menggabungkan model ARIMA yang diperoleh dengan hasil regresi pada langkah (2) menjadi model ARIMAX.

5. Melakukan pengujian efek GARCH melalui uji Autoregressive Conditional Heteroskedasticity-Lagrange Multiplier (ARCH-LM).

6. Melakukan pemodelan GARCH berdasarkan nilai residual model ARIMAX. Berikut adalah tahapan pemodelan ini:

a. Mengidentifikasi model dan melakukan estimasi parameter dalam metode Maximum Likelihood Estimation (MLE).

b. Melakukan pengujian signifikansi parameter.

c. Melakukan evaluasi model dan memilih model terbaik.

7. Melakukan peramalan dan mengukur akurasi model.

\section{HASIL PENELITIAN DAN PEMBAHASAN}

Pergerakan volume transaksi uang elektronik secara umum menunjukkan tren yang meningkat dengan rata - rata volume transaksi sebelum pandemi Covid- 
19 adalah sebanyak 134.210.640 dan rata - rata volume transaksi sejak pandemi Covid-19 hingga Desember 2020 adalah sebanyak 373.629.095. Peningkatan volume transaksi uang elektronik tersebut juga diikuti ketersediaan infrastruktur uang elektronik yang semakin memadai dengan rata - rata keseluruhan sebanyak 435.050 alat mesin reader. Pergerakan volume transaksi dan jumlah infrastruktur uang elektronik sejak 2013 hingga 2020 disajikan pada Gambar 1. Deskripsi data tersebut secara lengkap disajikan pada Tabel 2.

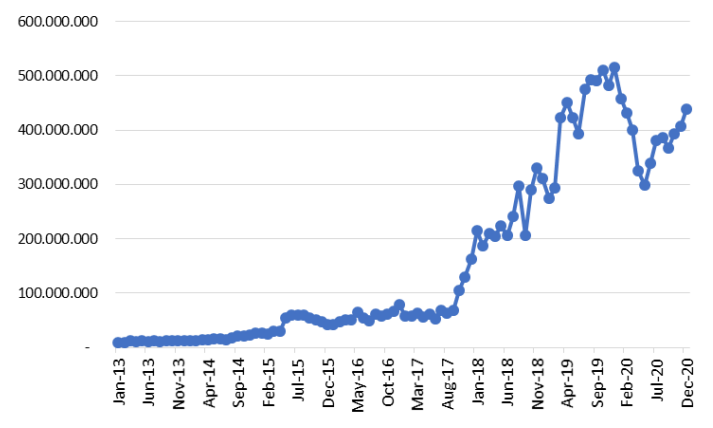

(a)

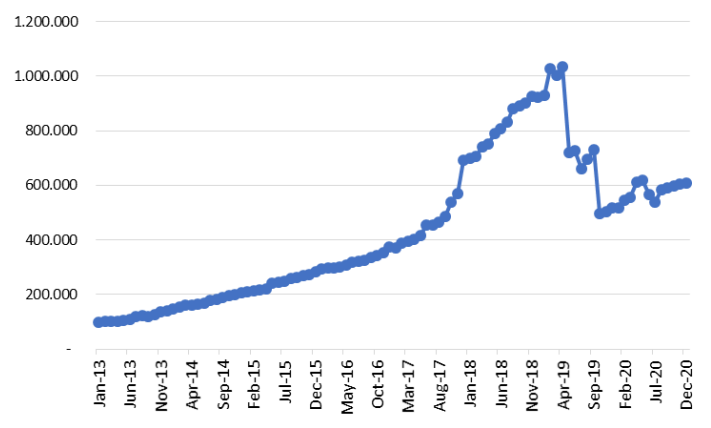

(b)

Gambar 1. Pergerakan Data (a) Volume Transaksi Uang Elektronik dan (b) Jumlah Infrastruktur Uang Elektronik di Indonesia.

Tabel 2. Deskripsi Data Penelitian.

\begin{tabular}{ccccc}
\hline \multicolumn{5}{c}{ Volume Transaksi Uang Elektronik } \\
\hline Kondisi & Mean & Simpangan Baku & Minimum & Maksimum \\
\hline Sebelum Pandemi & 134.210 .640 & 156.849 .968 & 9.597 .739 & 515.195 .069 \\
Sejak Pandemi & 373.629 .095 & 41.933 .822 & 298.187 .348 & 438.047 .792 \\
Keseluruhan & 159.150 .062 & 166.084 .663 & 9.597 .739 & 515.195 .069 \\
\hline Kondisi & Infrastruktur Uang Elektronik & \\
\hline Sebelum Pandemi & 417.352 & Simpangan Baku & Minimum & Maksimum \\
Sejak Pandemi & 587.260 & 271.530 & 98.275 & 1.033 .705 \\
Keseluruhan & 435.050 & 262.214 & 98.275 & 1.033 .705 \\
\hline
\end{tabular}

Untuk melihat signifikansi variabel eksogen terhadap variabel respon, dilakukan regresi antar variabel tersebut. Rangkuman hasil regresi tersebut disajikan pada Tabel 3. Hasil regresi menunjukkan bahwa infrastruktur uang 
elektronik dan kondisi pandemi Covid-19 memberi pengaruh yang signifikan terhadap volume transaksi uang elektronik. Secara matematis, persamaan hasil regresi tersebut dapat dinyatakan sebagai berikut:

$$
Y=-51.481 .749+444,9 X+163.821 .279 P_{(1)}
$$

Tabel 3. Rangkuman Hasil Regresi.

\begin{tabular}{ccccc}
\hline Variabel & Coef & SE Coef & T-Value & P-Value \\
\hline Intersep & -51.481 .749 & 19.143 .022 & $-2,69$ & 0,008 \\
\hline$X$ & 444,9 & 38,5 & 11,55 & 0,000 \\
\hline$P$ & & & & \\
\hline$(1)$ & 163.821 .279 & 32.881 .764 & 4,98 & 0,000 \\
\hline
\end{tabular}

Namun, hasil regresi pada Tabel 3 memiliki residual yang tidak white noise. Hal tersebut dapat dilihat melalui grafik Autocorrelation Function (ACF) dan grafik Partial Autocorrelation Function (PACF) seperti yang disajikan pada Gambar 2. Oleh sebab itu, dilakukan pemodelan ARIMA berdasarkan data residual tersebut. Sebelum melakukan uji stasioneritas dalam membentuk model ARIMA, dilakukan transformasi data untuk membuat data bernilai positif. Hal ini perlu dilakukan guna mengatasi kelemahan dari salah satu uji stasioneritas yaitu Transformasi Box-Cox yang mensyaratkan data bernilai positif. Transformasi data tersebut secara matematis dapat dinyatakan sebagai berikut:

$$
Y^{\prime}=Y+138.764 .598
$$

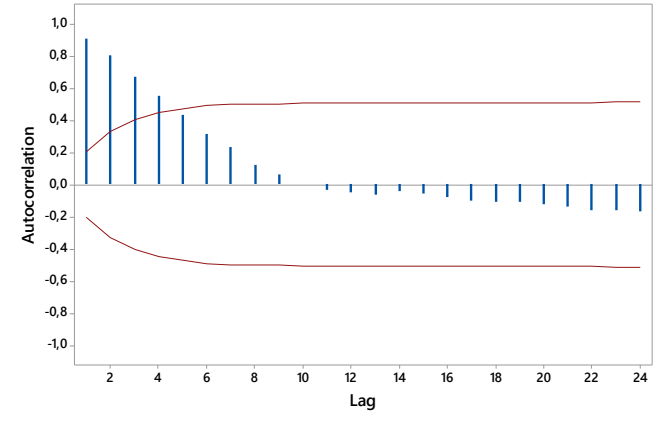

(a)

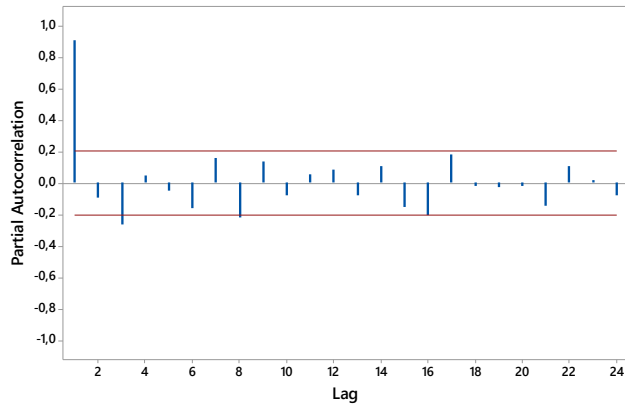

(b)

Gambar 2. Grafik (a) ACF dan (b) PACF dari Residual Hasil Regresi. 
Transformasi tersebut menunjukkan bahwa seluruh residual hasil regresi ditambahkan dengan nilai 138.764.598 sehingga seluruh residual tersebut bernilai positif. Langkah selanjutnya adalah uji stasioneritas. Dalam hal ini, uji stasioneritas dilakukan melalui Transformasi Box-Cox dan pengujian Augmented Dickey Fuller (ADF). Hasil pengujian menyimpulkan bahwa data belum stasioner dalam variansi. Hal ini ditunjukkan oleh nilai rounded value pada Gambar 3 yang menunjukkan angka sebesar 0,5. Selain itu, hasil pengujian ADF juga menunjukkan bahwa data masih belum stasioner dalam mean. Dengan demikian, diperlukan transformasi data kembali berdasarkan nilai rounded value yang diperoleh dari Transformasi Box-Cox dan dilakukan proses differencing. Nilai rounded value sebesar 0,5 menunjukkan bahwa data perlu ditransformasi dengan dipangkatkan 0,5. Dengan kata lain, diperlukan transformasi akar agar data stasioner dalam variansi. Transformasi tersebut secara matematis dapat dinyatakan sebagai berikut:

$$
Y^{\prime \prime}=\sqrt{Y+138.764 .598}
$$

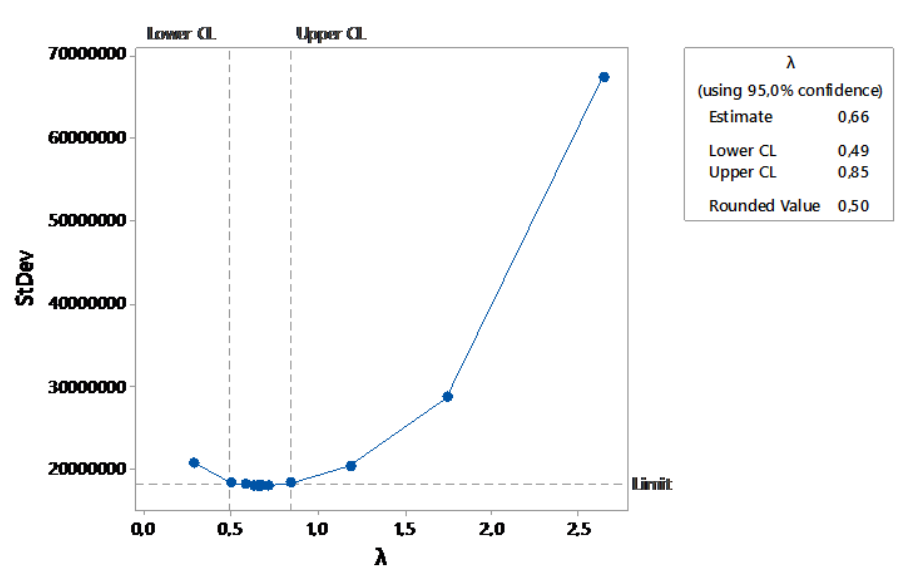

Gambar 3. Hasil Transformasi Box-Cox.

Hasil pengujian ADF sebelum dan sesudah dilakukan proses differencing diringkas dalam Tabel 4. Hasil pengujian tersebut menunjukkan bahwa data bersifat stasioner setelah melalui dua kali proses differencing. Dengan demikian, data telah memenuhi asumsi stasioneritas sehingga dapat dilakukan model ARIMA. Order yang mungkin untuk pemodelan ARIMA tersebut dapat ditinjau dari grafik ACF dan PACF. Berdasarkan grafik pada Gambar 4, diperoleh bahwa 
kurva ACF signifikan pada lag satu. Selain itu, kurva PACF signifikan pada lag satu hingga keempat. Hal ini mengindikasikan model ARIMA dengan order proses Autoregressive (AR) maksimum sebesar satu dan order proses Moving Average (MA) maksimum sebesar empat.

Tabel 4. Rangkuman Hasil Pengujian ADF.

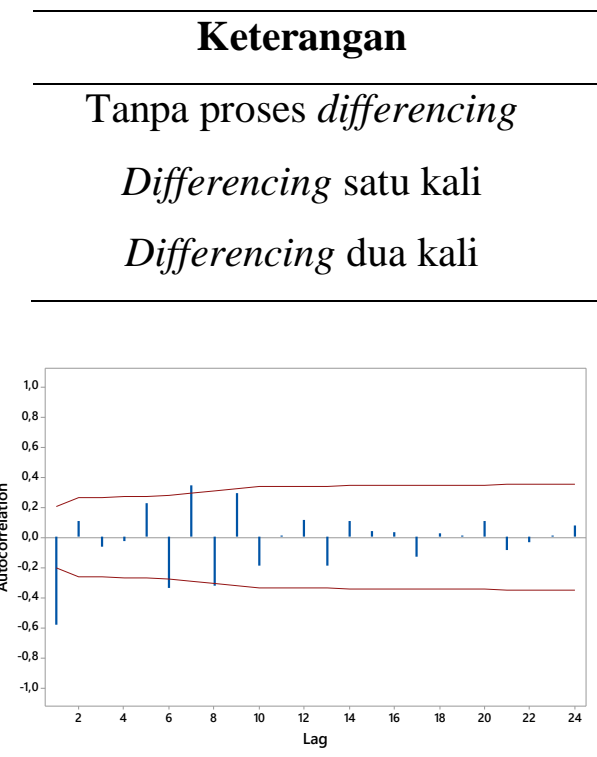

(a)

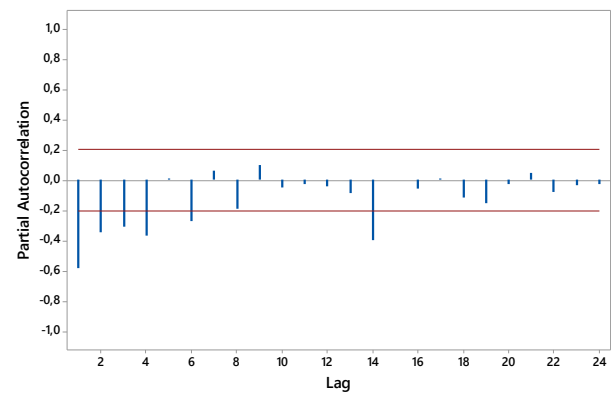

(b)

Gambar 4. Grafik (a) ACF dan (b) PACF Setelah Pengujian Stasioneritas.

Berdasarkan seluruh kemungkinan model yang dapat dibentuk, dipilih model ARIMA yang paling optimal dengan seluruh parameter signifikan, nilai Mean Square Error (MSE) terkecil, dan nilai AIC terkecil. Pada penelitian ini, model ARIMA yang dipilih adalah model probabilistik. Rangkuman hasil evaluasi model ARIMA yang seluruh parameternya signifikan ditampilkan pada Tabel 5. Berdasarkan hasil tersebut, diperoleh bahwa model $\operatorname{ARIMA}(0,2,1)$ merupakan model paling optimal. Secara matematis, persamaan model $\operatorname{ARIMA}(0,2,1)$ yang diperoleh dapat dinyatakan sebagai berikut:

$$
(1-B)^{2} Y_{t}^{\prime \prime}=(1-0,9915 B) a_{t}
$$

Selanjutnya, dilakukan pembentukan model ARIMAX dengan cara menggabungkan hasil regresi pada bagian awal dengan hasil pemodelan ARIMA. 
Tabel 5. Rangkuman Hasil Evaluasi Model ARIMA.

\begin{tabular}{ccc}
\hline Model ARIMA & Nilai MSE & Nilai AIC \\
\hline ARIMA(4,2,0) & 4.791 .922 & 1453,95 \\
ARIMA(3,2,1) & 5.668 .213 & 1469,74 \\
ARIMA(3,2,0) & 5.520 .221 & 1465,25 \\
ARIMA(2,2,0) & 6.034 .391 & 1471,62 \\
ARIMA(1,2,0) & 6.776 .606 & 1480,53 \\
ARIMA(0,2,1) & 4.346 .952 & 1438,79 \\
\hline
\end{tabular}

Dengan demikian, diperoleh model $\operatorname{ARIMAX}(0,2,1)$ yang secara matematis dinyatakan sebagai berikut:

$$
Y_{t}=-51.481 .749+444,9 X+163.821 .279 P_{(1)}+\left(\frac{(1-0,9915 B) a_{t}}{(1-B)^{2}}\right)^{2}
$$

Dengan asumsi bahwa $a_{t}$ merupakan error yang berdistribusi normal dengan nilai parameter mean sebesar nol dan variansi $\sigma^{2}$.

Selain itu, residual model $\operatorname{ARIMAX}(0,2,1)$ tersebut telah memenuhi asumsi white noise. Hal tersebut dapat dilihat berdasarkan grafik ACF dan PACF dari residual model ARIMAX yang disajikan pada Gambar 5. Namun, model ini terindikasi mengalami kasus heteroskedastisitas yang ditunjukkan oleh Gambar 6. Kuadrat residual yang signifikan pada lag satu kurva ACF dan PACF menunjukkan adanya kasus heteroskedastisitas. Oleh sebab itu, diperlukan pemodelan GARCH guna mengatasi masalah heteroskedastisitas yang terjadi pada residual model ARIMAX.

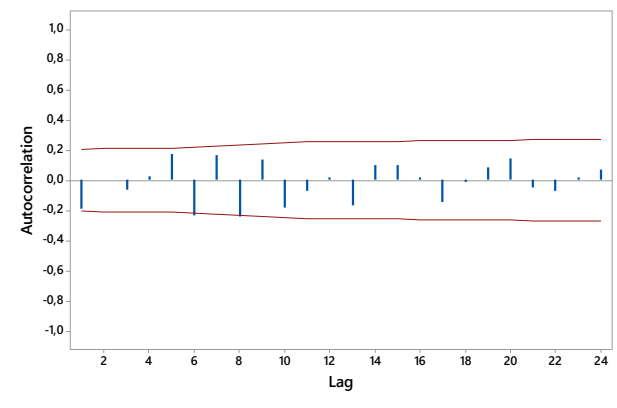

(a)

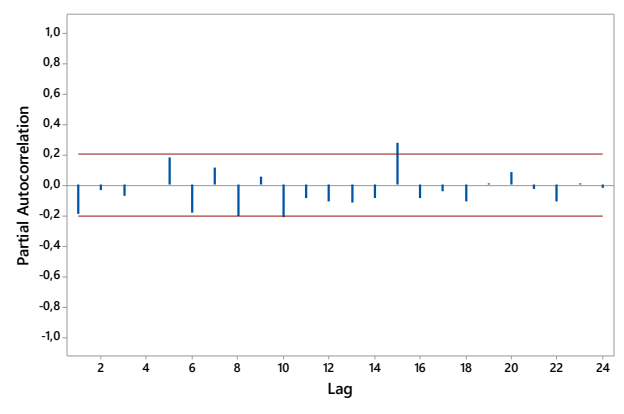

(b)

Gambar 5. Grafik (a) ACF dan (b) PACF dari Residual Model ARIMAX. 


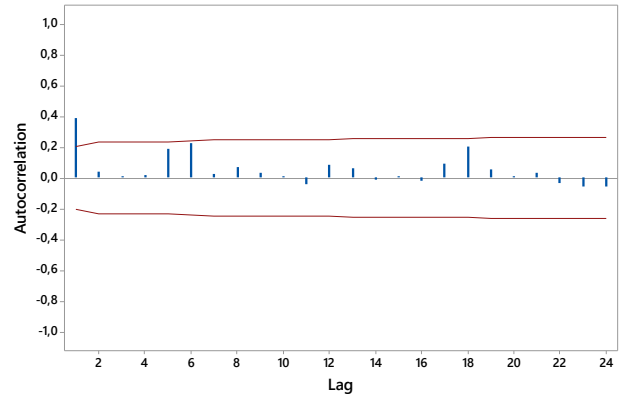

(a)

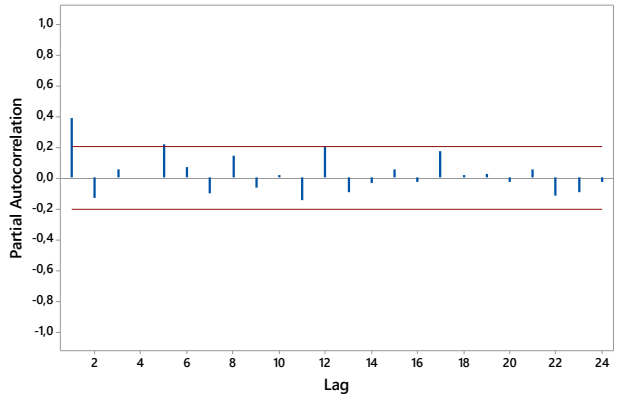

(b)

Gambar 6. Grafik (a) ACF dan (b) PACF dari Kuadrat Residual Model ARIMAX.

Sebelum melakukan pemodelan GARCH, dilakukan pengujian ARCH-LM untuk melihat signifikansi efek ARCH yang terjadi. Dalam hal ini, pengujian efek ARCH dilakukan pada lag pertama karena kurva ACF dan PACF pada Gambar 6 menunjukkan signifikan pada lag tersebut. Hasil pengujian tersebut dirangkum pada Tabel 6. Berdasarkan pengujian ARCH-LM, diperoleh nilai LM sebesar 14,37. Nilai tersebut telah memenuhi kriteria uji ARCH-LM pada tingkat kesalahan 5\% yaitu LM > 3,842. Oleh sebab itu, diperoleh kesimpulan bahwa kasus heteroskedastisitas signifikan pada lag pertama. Dengan demikian, pemodelan GARCH dilakukan dengan mempertimbangkan berbagai kemungkinan model pada order sebesar satu.

Tabel 6. Rangkuman Pengujian ARCH-LM.

\begin{tabular}{ccccc}
\hline Lag & T-Value & $\boldsymbol{P}$-Value & $\boldsymbol{R}$-Square & LM \\
\hline Pertama & 4,08 & 0,000 & $15,45 \%$ & 14,37 \\
\hline
\end{tabular}

Rangkuman hasil estimasi model GARCH pada setiap kemungkinan model disajikan pada Tabel 7. Dalam penelitian ini, model GARCH yang dipilih merupakan model yang paling optimal, dimana seluruh parameter signifikan dan memiliki ukuran kebaikan model seperti nilai AIC minimum, Schwarz Criterion (SC) minimum, dan Hannan-Quinn Criterion (HQ) minimum. Berdasarkan Tabel 7, diperoleh bahwa model $\operatorname{GARCH}(0,1)$ merupakan model yang paling optimal. Model GARCH $(0,1)$ tersebut dapat ditulis sebagai berikut:

$$
\sigma_{t}^{2}=-4756,197+1,1126 \sigma_{t-1}^{2}
$$


Tabel 7. Rangkuman Hasil Estimasi Model GARCH.

\begin{tabular}{ccccc}
\hline \multirow{2}{*}{ Model } & Signifikansi & \multicolumn{3}{c}{ Ukuran Evaluasi Model } \\
\cline { 3 - 5 } & Parameter & AIC & SC & HQ \\
\hline GARCH(1,0) & Signifikan & 17,2067 & 17,2608 & 17,2286 \\
GARCH(0,1) & Signifikan & 16,7319 & 16,7860 & 16,7537 \\
& Tidak & & & \\
GARCH(1,1) & Signifikan & 16,7383 & 16,8195 & 16,7711 \\
& & & & \\
\hline
\end{tabular}

Dari model ARIMAX $(0,2,1)-\operatorname{GARCH}(0,1)$ tersebut, dilakukan peramalan sebanyak 4 periode waktu selanjutnya. Hasil peramalan tersebut dibandingkan dengan nilai pada data testing yang digunakan untuk mengukur akurasi model yang diperoleh. Hasil peramalan tersebut dituliskan pada Tabel 8.

Tabel 8. Hasil Peramalan.

\begin{tabular}{ccc}
\hline Periode & Data Aktual & Hasil Peramalan \\
\hline Januari 2021 & 381.705 .947 & $455.225 .147,3$ \\
Februari 2021 & 360.064 .302 & $462.123 .714,3$ \\
Maret 2021 & 420.510 .643 & $464.797 .022,9$ \\
April 2021 & 421.606 .419 & $468.770 .731,1$
\end{tabular}

Hasil peramalan tersebut memperlihatkan bahwa nilai peramalan secara keseluruhan mampu mengikuti tren dari data aktual. Hal ini menunjukkan bahwa model ARIMAX $(0,2,1)-\operatorname{GARCH}(0,1)$ telah memiliki kemampuan yang baik dalam meramalkan volume transaksi uang elektronik di Indonesia. Nilai MAPE dari model tersebut adalah sebesar $11,33 \%$ yang artinya model ini telah masuk dalam kategori model dengan akurasi tinggi (Moreno, et. al., 2013; Andreas, et. $a l ., 2021$ a). Plot antara data aktual beserta hasil peramalan dari model yang telah diperoleh disajikan pada Gambar 7.

Hasil penelitian ini menunjukkan bahwa akurasi dari model ARIMAXGARCH dalam meramalkan volume transaksi uang elektronik di Indonesia memiliki akurasi yang lebih baik daripada penelitian sebelumnya. Pada penelitian sebelumnya, Sediono, et. al. (2021) menunjukkan bahwa nilai volume transaksi uang elektronik saling bergantung antar periode waktu. Hal tersebut juga dikonfirmasi dalam pemodelan ARIMAX-GARCH yang mengandung proses AR 
dan MA. Hal ini menunjukkan bahwa pemodelan time series cocok digunakan untuk meramalkan volume transaksi uang elektronik di Indonesia.

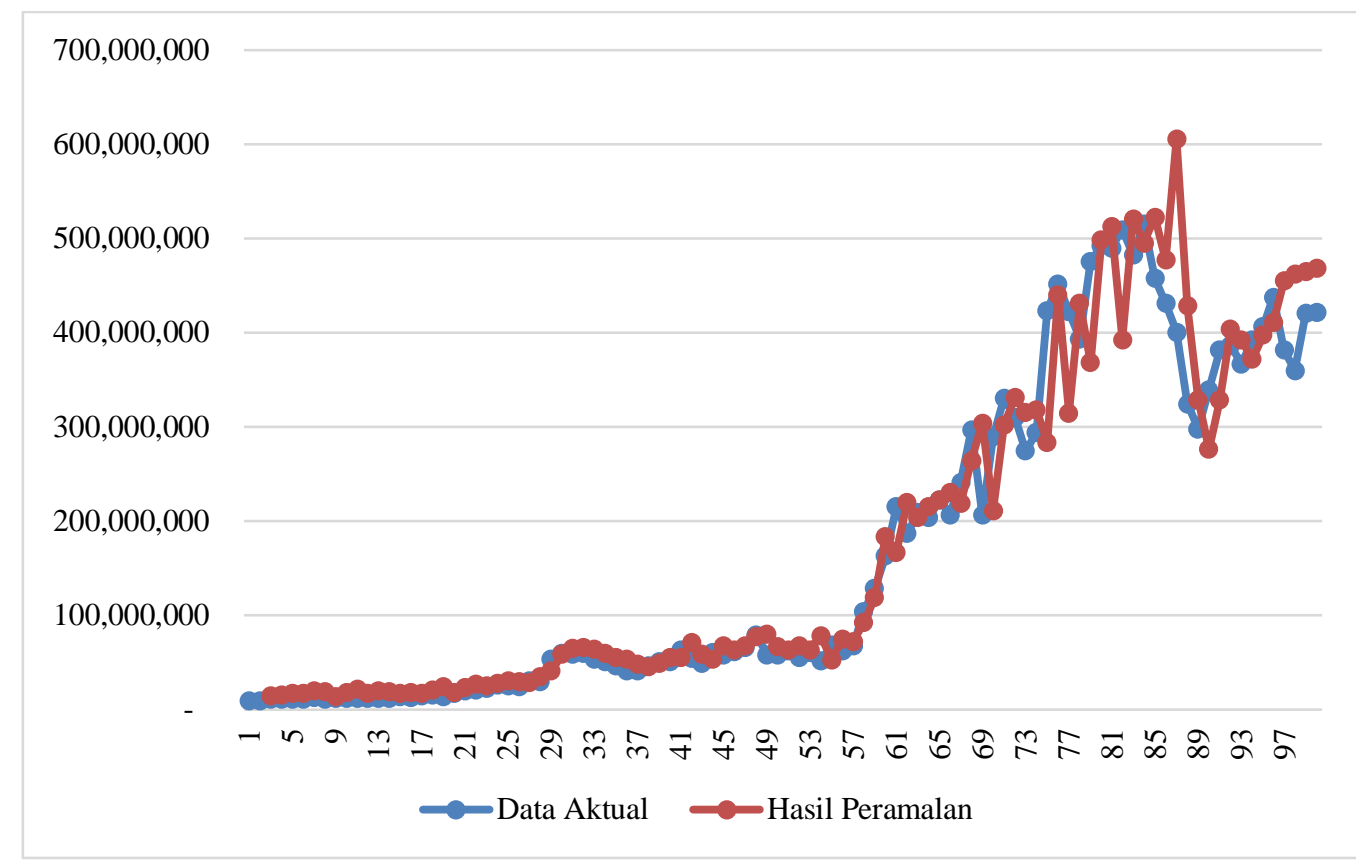

Gambar 7. Plot Data Aktual Beserta Hasil Peramalan.

Secara lengkap, hasil pemodelan ARIMAX-GARCH pada penelitian ini dapat dituliskan sebagai berikut:

Persamaan Mean

$$
Y_{t}=-51.481 .749+444,9 X+163.821 .279 P_{(1)}+\left(\frac{(1-0,9915 B) a_{t}}{(1-B)^{2}}\right)^{2}
$$

Persamaan Variansi

$$
\sigma_{t}^{2}=-4756,197+1,1126 \sigma_{t-1}^{2}
$$

Dengan asumsi bahwa $a_{t}$ adalah error dengan distribusi normal dengan mean dan variansi berturut - turut sebesar nol dan $\sigma^{2}$.

Lebih lanjut, pemodelan ARIMAX-GARCH pada penelitian ini juga mampu menunjukkan besar pengaruh dari variabel eksogen yaitu infrastruktur uang elektronik dan kondisi pandemi Covid-19. Berdasarkan model ARIMAXGARCH yang diperoleh, dapat disimpulkan bahwa peningkatan jumlah infrastruktur uang elektronik sebanyak satu mesin reader, akan meningkatkan volume transaksi uang elektronik sebesar 445 transaksi. Selain itu, kondisi 
pandemi Covid-19 ikut mendukung peningkatan nilai variabel respon yaitu volume transaksi uang elektronik di Indonesia. Adanya kondisi pandemi Covid-19 memberikan dampak terhadap peningkatan volume transaksi uang elektronik sebesar 163.821.279 transaksi dibandingkan sebelum adanya pandemi. Hal ini menunjukkan bahwa gerakan cashless selama pandemi Covid-19 memberi dampak signifikan terhadap volume transaksi uang elektronik.

\section{SIMPULAN}

Penelitian menunjukkan bahwa pemodelan time series dengan model ARIMAX-GARCH memiliki akurasi yang baik dalam meramalkan volume transaksi uang elektronik yang dipengaruhi infrastruktur uang elektronik dan kondisi pandemi Covid-19 di Indonesia. Dalam hal ini, infrastruktur uang elektronik dan kondisi pandemi Covid-19 memberi dampak positif terhadap peningkatan volume transaksi uang elektronik di Indonesia. Lebih lanjut, penelitian ini bermanfaat sebagai rujukan dalam mengevaluasi kebijakan terkait perkembangan ekonomi digital di Indonesia, khususnya penggunaan uang elektronik di Indonesia seperti upaya - upaya untuk meningkatkan penggunaan volume transaksi uang elektronik dapat didorong melalui penyediaan infrastruktur uang elektronik yang semakin memadai di setiap wilayah. Penelitian lebih lanjut dapat dilakukan dengan menambah periode waktu dalam pembentukan model sehingga model yang diperoleh memiliki akurasi yang semakin tinggi. Selain itu, pemodelan juga dapat dilakukan dengan mempertimbangkan pendekatan lain seperti pendekatan machine learning guna dibandingkan akurasinya dengan model dari pendekatan time series.

\section{UCAPAN TERIMA KASIH}

Terima kasih kepada seluruh pihak yang turut berkontribusi baik secara langsung maupun tidak langsung dalam mendukung proses terlaksananya kegiatan penelitian dan penyusunan artikel ilmiah ini.

\section{DAFTAR PUSTAKA}

Andreas, C., Harianto, F. Y., Safitri, E. J., dan Chamidah, N. (2021a). Analyzing The Effect of BI 7-Days Repo Rate on The Jakarta Composite Index Using 
Nonparametric Regression Approaches Based on Least Square Spline Estimator. Jurnal Matematika, Statistika \& Komputasi, 17(3), 447-461.

Andreas, C., Rahmayanti, I. A., Ulyah, S. M. (2021b). "The Impact of US-China Trade War in Forecasting The Gold Price Using ARIMAX Model". In AIP Conference Proceedings (Vol. 2329, p. 060011). AIP Publishing.

Aryani, S., Kuswanto, H., Suhartono. (2015). "Modeling Inflation Volatility Using ARIMAX-GARCH". In International Conference on Science, Technology, and Humanity (p. 188-197).

Bank Indonesia. (2020). Electronification. Diakses pada 02 Oktober 2021, dari https://www.bi.go.id/en/fungsi-utama/sistem-pembayaran/ritel/elektronifi kasi/default.aspx.

Bank Indonesia (2021a). E-Money Transaction. Diakses pada 02 Oktober 2021, dari https://www.bi.go.id/en/statistik/ekonomi-keuangan/ssp/uang-elektro nik-transaksi.aspx.

Bank Indonesia. (2021b). Infrastructure of E-Money. Diakses pada 02 Oktober 2021, dari https://www.bi.go.id/en/statistik/ekonomi-keuangan/ssp/uangelektronik-infrastruktur.aspx.

Cryer, J. D. dan Chan, K. S. (2008). Time Series Analysis with Application in R, $2^{\text {nd }}$ Edition. New York: Springer.

Indrawati, M., Nabila, K., Manewalu, M. O., Firmansyah, R. (2021). Penggunaan Aplikasi Dompet Digital di Masa Pandemi Covid-19. Prosiding National Seminar on Accounting, Finance, and Economics (NSAFE), 1(8), 235-247.

Kanmar, N. P. (2014). The Use of Electronic Money and Its Impact on Monetary Policy. Journal of Contemporary Economic and Business Issues, 1(2), 7982.

Moreno, J. J., Pol, A. P., Abad, A. S., dan Blasco, B. C. (2013). Using R-MAPE Index as a Resistant Measure of Forecast Accuracy. Psicothema, 25(4), 500-506.

Organisation for Economic Co-operation and Development. (2020). Digital Transformation in the Age of Covid-19: Building Resillience and Bridging Divides. Diakses pada 23 September 2021, dari https://www.oecd.org/digital/digital-economy-outlook-covid.pdf.

Rahmayanti, I. A., Andreas, C., Ulyah, S. M. (2021). Does US-China Trade War Affect The Brent Crude Oil Price? An ARIMAX Forecasting Approach. In AIP Conference Proceedings (Vol. 2329, p. 060010). AIP Publishing.

Sediono, Ana, E., dan Ardhiansyah, F. M. (2021). Modelling Electronic Money Transaction Volumes Based on The Intervention Analysis. In AIP Conference Proceedings (Vol. 2329, p. 060026). AIP Publishing.

Tsay, R. S. (2010). Analysis of Financial Time Series, 3th Edition. New Jearsey: Wiley.

Ulfi, I. (2020). Tantangan dan Peluang Kebijakan Non-Tunai: Sebuah Studi Literatur. Jurnal Ilmiah Ekonomi Bisnis, 25(1), 55-65.

Ulyah, S. M., Andreas, C., Rahmayanti, I. A. (2021). Forecasting Gold and Oil Prices Considering US-China Trade War Using Vector Autoregressive with Exogenous Input. In AIP Conference Proceedings (Vol. 2329, p. 060020). AIP Publishing.

Wolters, M dan Wieland, V. (2012). Forecasting and Policy Making. Institute for Monetary and Financial Stability, 62. 